\title{
IMPLEMENTATION OF SMART GOVERNANCE CONCEPT POLICY IN BANTUL REGENCY
}

\author{
Methafiani Tri Rezeki Farikhah \\ International Program of Government Affairs and Administration, \\ Universitas Muhammadiyah Yogyakarta \\ Email:methafiani@gmail.com
}

\begin{abstract}
This aims to know about what is the implementation of smart governance concep policy in Bantul Regency. This research uses descriptive qualitative research methods. Bantul Regency Government provides a smart city application to facilitate community participation in reporting an incident that occurs in the Bantul Regency environment. This application was created to be a means of fast and effective information between the public and the government. Not many people know, and there are some features that are either not understood by the community or do not facilitate the work done by LAPOR! Staff. Most complaints in Bantul Regency are dominated by complaints about infrastructure, the environment, bureaucratic reform and governance, population administration and several other problems. What is expected from the results of this study is the LAPOR! this becomes a bridge to connect complaints and aspirations of the community with relevant agencies, so that the issues raised can be conveyed and get a quick and appropriate treatment.
\end{abstract}

Keywords : Bantul Regency, LAPOR, Application, Smart City, ICT

\section{BACKGROUND}

Bantul is carried out with the concept of structuring cities and communities with digital technology to improve the performance and welfare of the community, by reducing costs and resource consumption and interacting more effectively with residents of Bantul. With key efforts the 'smart' sectors involved health services, education services, improved tourism, transportation, energy, water management and waste management. Able to provide a quick response to the challenges inherent in Bantul District with a simple 'transactional' relationship with the population (Kusumaningsih \& Kawuningrum, 2017).

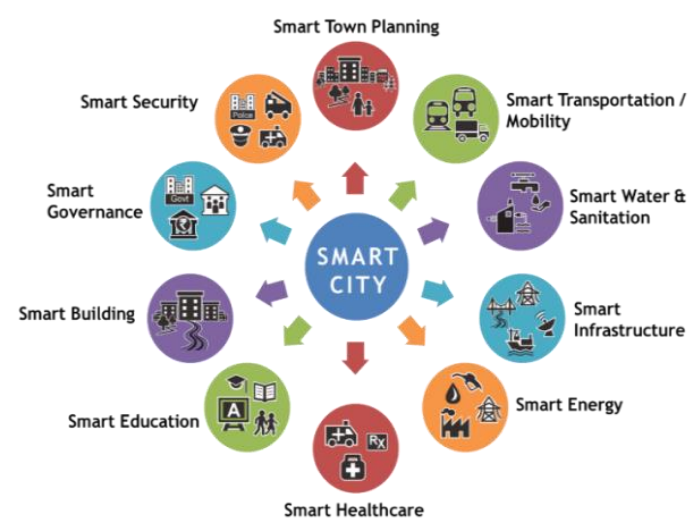

The concept of smart city can improve time and increase the ease in accessing information in a city in detail, complete, accurate and value (Giordano, Spezzano, \& Vinci, 2016). Smart Governance also plays an important role to realize the concept of smart city. Transparency and openness are key to the governance that carries the smart city. In addition, access to public services must be in accordance with the needs of the community 
and not complicate society.(Wu, Zhang, Shen, Mo, \& Peng, 2018)

Smart City is a concept that does not yet have a standard definition. Both in theoretical and empirical research. But, of all the definitions that you can find has one basic definition of this Smart City concept. The basic definition of Smart City is a city that has a space that can improve the daily lives of its citizens such as education, work, housing and so on in a wider scope. If viewed from a different perspective, Smart City is a concept to improve social, political, economic and government life (Rodríguez-Bolívar, 2015).

Problems in finding detailed, complete, accurate and time-saving information can be solved with open data systems. This system is an open data where all can be accessed freely, reusable or redistributable and this system can support the concept of smart city(Hashem et al., 2016) . The relatively rapid growth of population in urban areas raises a variety of urban issues, such as the decline in public service quality, reduced settlement of residential land, traffic congestion, difficulty getting parking, Energy consumption levels, garbage buildup, increased criminal figures, and other social issues(Dameri, 2017). These problems will continue to grow as the population grows and all these problems cannot be resolved quickly and appropriately if they are still using conventional solutions used today. Therefore, in order to solve the problem and realize the city's ideals (safe and comfortable) for its inhabitants, a clever solution is needed in order to resolve the problem can be done faster than the growth of the problem itself. The intelligent solution here is with the implementation and collaboration of the city ecosystem that goes into the Smart City concept. In this concept of Smart City solutions, governments, industry, academia, and community are involved to make the city better (Su, Li, \& Fu, 2011).
The implementation of e-government policies is helped by how to bring about transparent governance and provide good public services (Rodríguez-Bolívar, 2015). Smart city how to maximize the resources in Bantul area efficiently to improve the welfare of the people in Bantul city. Related to community service in Bantul. In order to realize Bantul as a smart city, the acceleration of nthe development of quality, affordable and integrated IT infrastructure from various sectors so that data monitoring and services can run simultaneously is an absolute prerequisite. The use of the internet which penetrated the field of government known as egovernment has become a mandatory instrument to connect the government with the community. To realize Bantul, smart city that must be fulfilled is to facilitate the need for information access for the community. This aims to know about what is the implementation of smart governance concep policy in Bantul City.

\section{LITERATURE REVIEW Smart city}

Smart City emerges from the need for an urban concept that can provide a sustainable living for its citizen as increasing urban populations (Mutiara, Yuniarti, \& Pratama, 2018). The idea of the smart city has arisen because of two dynamisms circumstance. The first is an enhancement of technology development and the second is drawing of people's needs. Urban issues resolved by an attainment of science and technology (Susanti, Soetomo, Buchori, \& Brotosunaryo, 2016)

Accroding to (Meijer \& Bolívar, 2016) Smart City is a city that uses digital technology to improve its performance, reduce costs and consumption consumption, and to engage more actively and effectively with its citizens. Smart city is an urban development to integrate information and communication technology 
(ICT) and Internet of things (IoT) technology in a safe way to manage city assets. Smart city is aimed at using urban information technology and technology to improve service efficiency. ICTs enable city officials to interact directly with the community and urban infrastructure and monitor what is happening in the city, how the city is developing, and how to create a better quality of life. Conceptualize smart city governance as an emerging socio-techno activity. Whether technology or social structure and a limited understanding of the relations between them and the development of socio-techno activities are emphasized in current literature. Academic research needs to investigate how insmart community activities are being strengthened. Analyze the participation to economic development and other public principles of smart city governance. Clear assessment studies of the effects of smart city governance on achieving both economic growth and other community values.

As stated by (Rodríguez-Bolívar, 2015) smart city is a "booming" phenomenon, which is still ambiguous in literature. Many different sciences look into the smart city domain and this can be met both in the ac- ademia (from the involved journals, schools and scholars) and the industry. Almost all sciences can be met in the smart city domain, which approach this phenomenon from different perspectives. Scholars and schools across the world are being or have been investigated this phenomenon and an indicative "picture" is provided. On the other hand, three alternative industries appear to meet in this domain and create an emerging corresponding market: the ICT, the construction, and the electronics.

(Rodríguez-Bolívar, 2015) mentioned the move from ordinary cities to smart cities uses technology components with politics and safety. The political component represents various elements and external pressures, such as political policy that might influence the idea of smart city making. Important information is very important for understanding the use of information systems. Innovative government that participates in building smart cities to manage changes in a policy.

\section{Smart Governance}

According to (Almirall et al., 2016) EGovernance is digital governance. Egovernance or electronic governance is a form of governance that is carried out by the central and regional governments in conducting public services to the community based on technology. Governance in a country cannot be separated from internal conditions both macro and micro from the country concerned, so that its understanding is very much determined by history, culture, education, political views, economic conditions, of the country concerned and the vision and mission, as well as a development strategy a very unique country resulted in a variety of approaches and scenarios in the process of national development so that it affects the development of national priorities.

(Meijer \& Bolívar, 2016) mentioned stated that throughout their concept as the defining feature of a smart city, the publications with a focus on governance highlight the interactions between various stakeholders in the community. Smart cities are seen from a user-centered viewpoint with more focus on residents and other stakeholder .(Shamsi, Ameen, Isaac, Shibami, \& Khalifa, 2018) analyzed that from the literature on smart governance and e-government, definitions exist, but in simple words, egovernment can be defined as ' the use of information and communication technology (ICT), and especially the Internet, as a tool for achieving better governance.

(Mutiara et al., 2018) mentioned the establishment of clear laws and freedom of 
opinion or democracy also needs to be realized in order to guarantee the security, safety and comfort of the people. The government's plan to improve the real development structure, control economic flows, and resource management is also an effort that the government can do to start reducing imports and start utilizing agricultural products supported by native human resources. And the most important thing in creating Smart Government is the formation of professional, responsible and clean character of government.

According to (Dameri, 2017) The introduction of smart cities usually grows like a bottom-up trend, that is, many players begin to carry out a smart initiative independently, using certain public infrastructure or technological solutions. A knowledge city is a community that seeks to grow knowledge by promoting ongoing knowledge creation, sharing, assessment, replication, and updating. This can be done through the constant contact between their own people and between them and the residents of other cities at the same time. Such interactions are facilitated by the knowledge-sharing culture of the community as well as the correct architecture, IT networks and infrastructures of the city. E-governance has 3 main actors, namely:

a. Government as a policy maker certainly plays an important role in granting policies, permits, monitoring, and carrying out the aspirations of the community and representing the regions and countries in cooperation with business people as well as with other regions or countries

b. Citizens are groups or actors in egovernance that act as monitors in the governance process. Both in terms of providing input, criticism, connoisseurs of services provided by the government, as well as being a Human Resources needed both the government and the private (business) environment.

c. Business or Interest Group (entrepreneurs, private parties, and related parties) Within this group there are groups of individuals, organizations involved in business, industrial, sales, purchasing and distribution activities. These business groups will form a Governance to Business (G2B) relationship. The main meran of business groups in e-governance is as a driving force to provide human resources and technology implementation for the implementation of e-government and egovernance for government and society.

\section{RESEARCH METHOD}

The data collected in the study did not consist of numbers, the data obtained earlier from interviews, field notes, personal documents, memos, and other official documents. Related to the objective of this qualitative research is to review the empirical reality behind the phenomenon that is complete and detailed. This research uses descriptive qualitative research methods.

Data source Secondary is data obtained from reading sources and various other sources consisting of personal letters, diaries, minutes of association meetings, to official documents from various government agencies. Secondary data can also be magazines, bulletins, publications from various organizations, attachments from official bodies such as ministries, study results, theses, survey results, historical studies, and so on.

Data collection in this study uses several methods to obtain complete data. The method used to collect data in this study is observation, interviews and documentation.

\section{Documentation}

Document study is a way to collect data and study literature, where documents 
that are considered to be supportive and relevant to the problem to be examined either in the form of literature, annual reports, magazines, journals, tables, scientific papers on government regulatory documents and available laws related institutions are studied, reviewed and arranged / categorized in such a way that data can be obtained to provide relevant information.

2. Observation

Direct observation is a way of retrieving data using the senses without the help of other standard tools for this purpose. In our daily activities, we always use our eyes to observe something. Observation is one of the most important research techniques.

\section{FINDINGS AND DISCUSSION}

Based on the data from the web of Bantul local government explain that the Bantul Smart City Program is a system of public service delivery to the public through an internet network that is connected to all relevant agencies and institutions that can be accessed by the community aimed at improving the welfare and quality of people's lives. Bantul's smart city is not a goal, but a means of empowering the potential around us that requires different innovations to achieve a goal. The aim is to improve people's wellbeing and quality of life. Smart City is an effective and efficient management of all local resources to address various challenges by promoting the use of ICT, using creative, integrated and sustainable solutions to enhance people's services and quality of life. Smart City is an effective and efficient management of all local resources to address various challenges by promoting the use of ICT, using creative, integrated and sustainable solutions to enhance people's services and quality of life.
Every effort and effort of Diskominfo Bantul creates new innovations in Bantul Report, he believes that this mobile application can help solve problems that arise in Bantul Regency. The Bantul Reporting launch is in line with the commitment of the Bantul Regency Government to improve public services and good governance through improving the quality of responsive bureaucracy. In Bantul Report, every initiative and effort by Diskominfo Bantul creates new inventions, he believes that this mobile application will help to solve problems that arise in Bantul Regency. The launch of the Bantul Reporting is in line with the Bantul Regency government's commitment to improving public services and good governance by improving the quality of responsive bureaucracy.

The purpose of developing channels Bantul LAPOR complaint application is for facilitate the community in give a complaint. Bantul LAPOR developed can be accessed through the website and this android smartphone can used wherever and whenever. this facilitates the delivery of information and complaints from the public to Bantul Regency government. Development of this Sleman Report application become more effective and efficient that is all reports directly connected to the agency that concerned.

The community is an important part of creating a smart city, because it is thus the habits that were once abandoned. Smart city projects have an impact on the quality of life of citizens with the aim of making a city more efficient. The community is also demanded to participate in the management and organization of the city, as well as being active city users. The community is also the most decisive factoryang success or failure of the creation of smart city.

Bantul Report is a service provided by the Office of Communication and Information 
of the Bantul Regency Government as a medium to channel complaints for residents and to handle all problems in the Bantul Regency area.

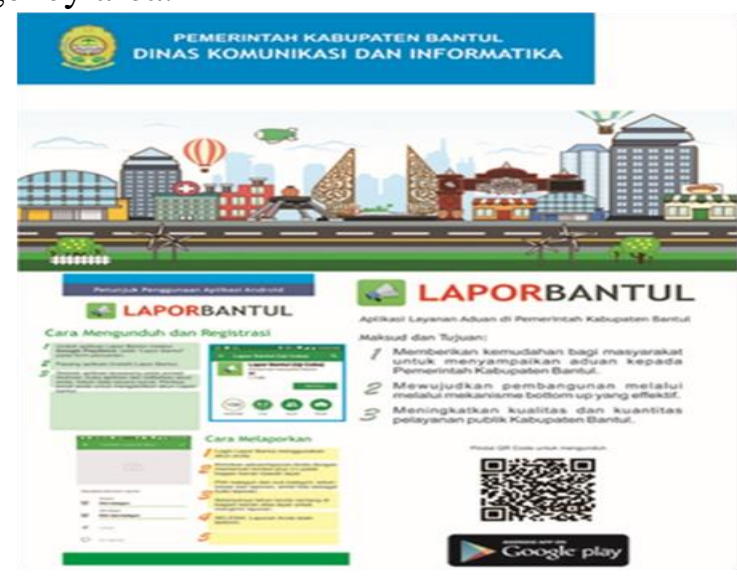

So based on public opinion Bantul Regency chose 5 star because they were satisfied with the application that was effective and functional, 4 and 3 star did not vote, 2 star felt less satisfied with the application service, and 1 star community was not satisfied with the application. But to understand the statistical results of all complaints related to whether it has been processed, is being processed or has not been processed can not be read in detail and not easily understood by the cloud, because the value of each complaint does not only show the smallest to largest range without knowing the actual number. Therefore the simplicity of the statistical results of all complaints still needs to be fixed again.

Bantul Regency Government carry out bureaucratic reform as a way to realize good governance. Good governance is one of the bantul components to realize becoming a Smart city. Smart city is a concept smart district in development and various management of resources effective and efficient by utilizing information

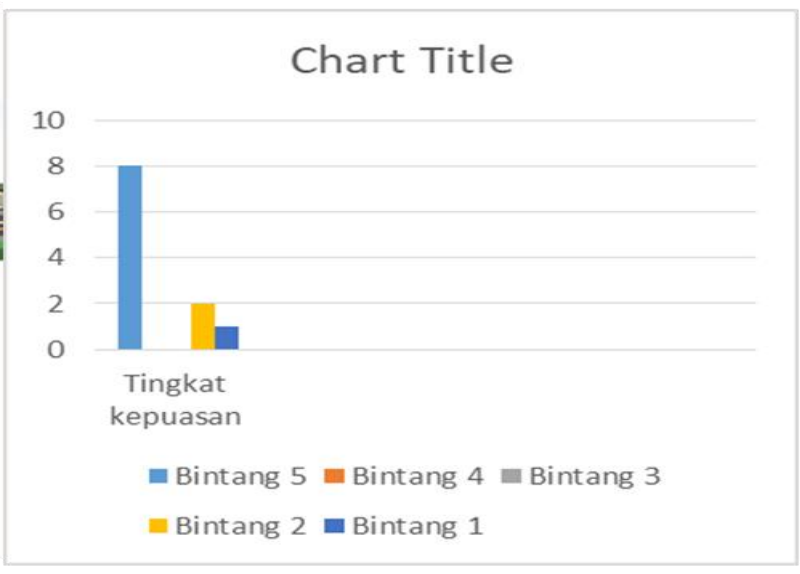

technology advancements and communication.

Conducting development with smart city is no longer an option, but has become a necessity in providing fast and efficient services. The main objective of developing a "Smart City" is how we preserve the environment, improve economic competitiveness and build a civil society. LAPOR is a social media application that involves public participation and is bi-directional, so that in this application the community can interact with the government interactively with easy and integrated principles for supervision of development and public services. Electronic services as deeds, businesses or performances that delivery is mediated by information. Overall, the Management of Online People's Complaint Aspirations Service in the Office of Communication and Information of Bantul City Government can be concluded that the existence of the People's Online Complaints Aspirations Service (LAPOR) is intended to facilitate the community as a place for complaints in issuing aspirations 
or complaints against the performance of the Bantul Regency government. Electronic services will also provide the ability and flexibility for the relevant institutions to collect the required data, reduce the error rate caused by manually re-inputing data and can be time consuming in the process of presenting data (Muhammad Hidayatullah, 2019).

Complaint services by utilizing technology, information, and communication (ICT) make it easier for the public to submit complaints. Bantul Lapor application based on android applications and this website can be accessed anywhere and anytime. People who use the Bantul Lapor application have a variety of objectives, among others, to try, give appreciation and input, and report problems in their environment. The Bantul Reporting Application as a new complaints service is more accessible and the submission of complaints is easier for the community.

The user community can find out the conditions in Bantul Regency besides that it can also be a function of government control whose reports are not immediately followed up. Another benefit that is felt is that there is a good response from the government making people feel easy to submit questions, appreciation, complaints, complaints, and suggestions.

In accordance with its purpose, the LAPOR system used as a place that can accommodate complaints or complaints from the public on public services that are still problematic. With reports from the public, it is expected that there will be improvements in public services that are considered to be lacking and there is an appropriate solution and resolution for any complaints or complaints that come from the community that are determined and implemented consequently.

\section{CONCLUSION}

Smart city is an alternative solution for the Regency of Bantul to overcome all the problems that exist in the city. This smart city program was adopted with the aim of providing more effective and efficient public services to all levels of society and referring to the vision of the Regency of Bantul as an inclusive city. Based on the results of research on the quality of disabled-friendly transportation services actually and through the perspective of the disabled in Bantul Regency. In socializing about the Smart City program requires a long process and must also be supported by the government and its citizens. Even though the government has launched policies to support Bantul as a Smart City, it still requires a considerable amount of time for its application to reach the residents of Bantul. Overall, the Management of Online People's Complaint Aspirations Service in the Office of Communication and Information of Bantul Regency Government can be concluded that the existence of the People's Online Complaints Aspirations Service (LAPOR) is intended to facilitate the community as a place for complaints in issuing aspirations or complaints against the performance of the Bantul Regency government. 


\section{REFERENCES}

Almirall, E., Wareham, J., Ratti, C., Conesa, P., Bria, F., Gaviria, A., \& Edmondson, A. (2016). Smart Cities at the crossroads: New tensions in city transformation. California Management Review, 59(1), 141-152. https://doi.org/10.1177/00081256166 83949

Dameri, R. P. (2017). Urban Smart Dashboard. Measuring Smart City Performance.

https://doi.org/10.1007/978-3-31945766-6_4

Giordano, A., Spezzano, G., \& Vinci, A. (2016). Smart Agents and Fog Computing for Smart City Applications (pp. 137-146). Springer, Cham. https://doi.org/10.1007/978-3319-39595-1_14

Hashem, I. A. T., Chang, V., Anuar, N. B., Adewole, K., Yaqoob, I., Gani, A., ... Chiroma, H. (2016). The role of big data in smart city. International Journal of Information Management, 36(5), 748-758. https://doi.org/10.1016/j.ijinfomgt.20 16.05.002

Kusumaningsih, R. Y. R., \& Kawuningrum, K. (2017). Konsep Desain Jaringan Komputer Yang Sesuai Untuk Kontur Wilayah Dalam Mewujudkan Bantul Smart City. Prosiding Sensei 2017, 1(1). Retrieved from http://jurnal.unmuhjember.ac.id/index .php/SENSEI17/article/view/846/681

Meijer, A., \& Bolívar, M. P. R. (2016). Governing the smart city: a review of the literature on smart urban governance. International Review of Administrative Sciences, 82(2), 392408. https://doi.org/10.1177/00208523145 64308

Mutiara, D., Yuniarti, S., \& Pratama, B. (2018). Smart governance for smart city. IOP Conference Series: Earth and Environmental Science, 126(1), 012073. https://doi.org/10.1088/17551315/126/1/012073

Rodríguez-Bolívar, M. P. (2015). Transforming city governments for successful smart cities. Transforming City Governments for Successful Smart Cities, 1998, 1-185. https://doi.org/10.1007/978-3-31903167-5

Shamsi, R. S. H. AL, Ameen, A. A., Isaac, O., Shibami, A. H. A.-, \& Khalifa, G. S. (2018). THE IMPACT OF INNOVATION AND SMART GOVERNMENT ON HAPPINESS: PROPOSING CONCEPTUAL FRAMEWORK. International Journal Of Management And Human Science, 2(2), 10-26. Retrieved from http://ejournal.lucp.net/index.php/ijm hs/article/view/820

Su, K., Li, J., \& Fu, H. (2011). Smart city and the applications. In 2011 International Conference on Electronics, Communications and Control (ICECC) (pp. 1028-1031). IEEE.

https://doi.org/10.1109/ICECC.2011. 6066743

Susanti, R., Soetomo, S., Buchori, I., \& Brotosunaryo, P. M. (2016). Smart Growth, Smart City and Density: In Search of The Appropriate Indicator for Residential Density in Indonesia. Procedia - Social and Behavioral Sciences, 227, 194-201. https://doi.org/10.1016/J.SBSPRO.20 16.06 .062 
NAKHODA: JURNAL ILMU PEMERINTAHAN

Edisi Juli Desember 2019 Volume: 18 Nomor: 2

ISSN : 1829-5827 | E-ISSN : 2656-5277

DOI : https://doi.org/10.35967/jipn

ILMU PEMERINTAHAN

https://nakhoda.ejournal.unri.ac.id/index.php/JIPN

Wu, Y., Zhang, W., Shen, J., Mo, Z., \& Peng, Y. (2018). Smart city with Chinese characteristics against the background of big data: Idea, action and risk. Journal of Cleaner Production, 173, 60-66. https://doi.org/10.1016/j.jclepro.2017. 01.047 